\title{
DŻUMA W ITALII. O ZAPOMNIANYM TRAKTACIE DELLA PESTE ANGELA ANTONIA FRARI
}

\author{
DOROTA KARWACKA-PASTOR
}

\begin{abstract}
Angelo Antonio Frari, a $19^{\text {th }}$ century doctor and writer, devoted his life to studying the plague. In his treaty entitled Della peste published in Venice in 1840, he presented the history of the plague pandemic, describing its symptoms and ways of curing throughout centuries. His work is not only a medical, anthropological, and ethical treaty, but also an account of events seen by a witness, who, having recovered from the plague, became involved in fighting with this disease in Italy and abroad. The author of the treaty delves into pondering on human nature, morality, and choices, and he presents various attitudes in the light of the epidemic. This work is also a source of information on how $19^{\text {th }}$ century healthcare used to work and contains tips on how to avoid catching the disease. The subject matter of the treaty is still up to date, since the last word of this disease has not been said yet and it continues to be a threat to the human race.
\end{abstract}

Key words: plague, treaty, Frari, Italy, human nature

Od zmierzchłych wieków przez Italię przetaczały się fale epidemii. Najstraszliwszą z chorób była peste nera, zwana w czternastym wieku morową zarazą albo czarną śmiercią. W języku włoskim stosowano przerażające określenie owych czasów pandemicznych - la mortelega grande, „wielkie umieranie”.

W przeciągu wieków dżuma zdziesiątkowała kraje europejskie i była największą pandemią w historii ludzkości. Pojawiła się w VI i VII wieku w cesarstwie bizantyńskim. W średniowieczu przybyła do Europy z Azji poprzez jedwabny szlak. W 1347 roku dotarła do Sycylii, a następnie do Genui. Zajęła cały Półwysep Apeniński. Występowała we Francji, Hiszpanii, Szwajcarii, Anglii, Szkocji i Irlandii, a po 1353 roku ogarnęła już całą Europę. Pochłonęła wówczas jedną trzecią populacji konty- 
nentu (Alchon 2003: 21), prawdopodobnie aż 20 milionów osób (Ujvari, 2002: 70). Od 1480 roku częstotliwość występowania fal epidemii dżumy malała, tak więc choroba uderzała już nie co kilka, a raczej co 15-20 lat. Między 1500 a 1850 rokiem dżuma pojawiała się regularnie także w krajach świata islamskiego.

Kroniki podają daty kolejnych dużych fal epidemii dżumy w Italii - w latach 1576-77 mór zaatakował Mediolan i okolice, w 1630 roku północne Włochy, potem pojawiał się sporadycznie na pozostałym terytorium Italii. W XVII w. zaraza występowała też w innych rejonach Europy, w Azji, także w imperium otomańskim. W czasie dziewiętnastowiecznej epidemii dżumy, która wybuchła początkowo w Chinach, życie straciły miliony ofiar w całej Azji. W XX wieku dżuma pojawiała się w Ameryce Północnej, a w latach 1900-1925 także w Australii (Aberth 2012: 31-105).

Europejskimi krajami najbardziej nawiedzanymi przez dżumę były Włochy i Francja. Christopher Duncan i Susan Scott piszą, że „Włochy były ciągle narażone przyjazdami zarażonych osób przybywających drogą morską" (Duncan, Scott 2008: 59). Zauważają, że już w 1337 roku kolonia wenecka w sycylijskiej Ragusie wprowadziła 30-dniową kwarantannę, która okazała się jednak za krótka. Średniowieczna dżuma charakteryzowała się bowiem długim okresem inkubacji. Ostatecznie ustalono optymalny okres 40 dni - taką kwarantannę zastosowano w Genui w 1652 roku oraz we Florencji w 1630 roku.

Pomiędzy 1349 a 1537 rokiem czarna śmierć zbierała żniwo w Italii mniej więcej co dwa lata. W XV wieku Neapol przeszedł dziewięć fal epidemii, a Mediolan aż osiemnaście w XVI wieku' ${ }^{1}$ W XVII wieku przez Italię przetoczyły się dwie fale epidemii - w latach 1630 i 1665. Ostatnia, największa pojawiła się w Messynie na Sycylii i w Reggio Calabria w 1749 roku (Ducan, Scott 2008: 59-100).

Gdziekolwiek pojawiały się ogniska dżumy, powstawał chaos, ludzie w popłochu ewakuowali się z miast. Choroba budziła przerażenie, bo nie znano jej przyczyn. Dzisiejsza medycyna informuje, że dżuma jest chorobą zakaźną o podłożu bakteryjnym, wywoływaną przez bakterie gram-ujemne Yersinia pestis z rodziny Enterobacteriaceae. Pałeczki dżumy są przenoszone ze zwierzęcia na człowieka przez pchły. W odmianie płucnej dżuma może przenosić się także drogą kropelkową. Yersinia pestis najpierw atakuje węzły chłonne, a potem z krwią rozsiewa się po całym organizmie. Czarna śmierć pojawiała się pod różnymi postaciami: dżumy dymieniczej (dymienicy, pestis bubonica) z obrzękiem węzłów limfatycznych, płucnej (pestis pneumonica) i septycznej (pestis septica) o przebiegu piorunującym. Wszystkie postaci dżumy mogą występować razem w czasie jednej fali epidemii (Duncan i Scott, 145-146).

W pismach, listach i literaturze minionych wieków epidemie były motywem często spotykanym. O dżumie czytamy w biblijnej I Księdze Samuela, wspominał o niej w Iliadzie Homer, Tukidydes w Wojnie peloponeskiej, Lukrecjusz w $O$ natu-

\footnotetext{
${ }^{1}$ Co dwa lata do 1528 roku, a potem co cztery lata do 1550 roku.
} 
rze wszechrzeczy, Wergiliusz w Georgikach, Owidiusz w Metamorfozach. W I wieku n.e. historyk longobardzki Paweł Diakon w Historii Longobardów oraz Procopiusz z Cezarei w Historii wojen opisali epidemię dżumy, która uderzyła w Ligurię, Rzym, Rawennę i Pawię w ostatnich latach rządów Justyniana ${ }^{2}$.

Włoski franciszkanin Michele da Piazza w Historia sicula ab anno 1337 ad annum 1361 ukazuje genezę i przebieg epidemii dżumy na Sycylii, pisząc o panice, przeszywającym ciała chorych bólu i o wzajemnej nienawiści panującej wśród przerażonych ludzi. Poeta Francesco Petrarka, który przeżył uderzenie epidemii w Parmie, odmalował dramatyczną sytuację w Italii w listach do przyjaciół oraz do brata zakonnika. Marchionne di Coppo Stefani opisał rozpacz i żałobę mieszkańców Florencji dotkniętej falą epidemii w Cronaca fiorentina. Matteo Villano wspominał o skutkach dżumy w swojej Cronica, a Giovanni Morelli w Ricordi.

W literaturze włoskiej jeden z najbardziej przejmujących opisów epidemii zawarty jest w Dekameronie. W kwietniu 1348 roku dżuma zbierała swe krwawe żniwo we Florencji. Boccaccio wspomina o fatalnym układzie planet i o ,słusznym gniewie Bożym” wywołanym niegodziwościami popełnianymi przez ludzi ${ }^{3}$. Relacjonuje:

Moc zarazy była tak wielka, że przenosiła się ona nie tylko z jednego człowieka na drugiego, ale i tak bywało, że jeśli do jakiejś rzeczy, stanowiącej własność chorego, podeszło zwierzę, zaraz mór je ogarniał i w krótkim czasie je zabijał (Boccaccio 1999: 5).

W 1481 roku filozof Marsilio Ficino pisze Consilio contro la pestilenza, gdzie analizuje naturę choroby, podkreśla wysoki stopień zaraźliwości i doradza, jak uniknąc zachorowania, kierując swe rady do osób zajmującym się chorymi. W 1523 roku Machiavelli w Epistola della peste parodiuje opis Boccaccia, a Francesco Berni w 1537 roku w Capitoli e sonetti burleschi ironizuje na temat dżumy, porównując ją do zmiennej i mściwej kobiety.

Epidemia pojawia się także w nowelach szesnastowiecznego prozaika Matteo Bandello oraz w Dialogo della peste pióra Paolo Bellintani (1584-90). O dżumie w Wenecji wspomina w 1576 roku Rocco Benedetti w Ragguaglio minutissimo della peste di Venezia.

Literatura włoska dokumentuje dokładnie dżumę mediolańską z 1630 roku dzięki słynnej powieści Narzeczeni oraz dziełu Storia della colonna infame autorstwa

\footnotetext{
${ }^{2}$ Także sam cesarz zachorował na dżumę. Dżuma Justyniana pojawiała się w cyklach dziewięciolub dwunastoletnich. W okresie od 541 do 700 roku spowodowała zmniejszenie populacji zamieszkującej wybrzeża Morza Śródziemnego o 50\% (Duncan, Scott: 2008: 208).

${ }^{3} \mathrm{~W}$ przypadku różnych fal epidemii snuto domysły dotyczące genezy. W średniowieczu zazwyczaj uznawano zarazę za karę boską. Potem uczeni minionych epok doszukiwali się przyczyn w „zepsutym powietrzu" czy wyziewach z głębi ziemi, pojawieniu się komety, w konstelacjach planet. Szukano kozłów ofiarnych - zwykle byli to „obcy”, czarownice, innowiercy, Żydzi, a także trędowaci. Zwykle karano ich okrutną egzekucją (Delumeau 1986: 100).
} 
Alessandra Manzoniego. Cenną skarbnicą wiedzy na ten temat jest też traktat kardynała Fryderyka Boromeusza De peste Mediolani quae fuit anno $1630^{4}$ oraz De pestilentia Giuseppe Ripamonti.

O florenckiej zarazie z lat 1630-33 czytamy u Giovanniego Baldinucci w Quaderno. Peste, guerra e carestia nell'Italia del Seicento. Na temat osiemnastowiecznej epidemii w Mesynie wypowiadali się sycylijscy arystokraci: Fracesco Maria Emanuele markiz Villabianca (Istruttioni), Orazio Turriano (Memoria istorica del contagio della citta di Messina), Enea Gaetano Melani (La peste di Messina accaduta nell'anno 1743) i Alfonso Varano w Visioni sacre e morali. O straszliwych skutkach dżumy w Noja (1815-6) pisał z kolei Vitangelo Morea w Storia della peste di Noja ${ }^{5}$.

Od wieków poszukiwano skutecznego remedium na dżumę. Szczególnie w XIX wieku próbowano odkryć, w jaki sposób rozprzestrzenia się choroba i czy można ją powstrzymać. Najbardziej kompletnym i kompetentnym źródłem z tamtego okresu jest obszerny traktat Della peste e della publica amministrazione samitaria, którego autorem jest włoski pisarz i lekarz, Angelo Antonio Frari. Żył w latach 1780-1865, ukończył studia medyczne w Padwie w 1801 roku, potem przebywał w Wiedniu, gdzie był uczniem słynnego Johana Petera Franka, prekursora stosowania higieny w medycynie. Pracował następnie w Splicie, gdzie zainteresował się epidemiologią. Zyskał sławę ze względu na swoje nowatorskie teorie na temat higieny i na wprowadzenie kwarantanny jako metody zapobiegania epidemiom. W tym zakresie wpłynął nawet na lokalne prawo. W czasie epidemii dżumy w Splicie, a także w Czarnogórze i Albanii angażował się aktywnie $\mathrm{w}$ walkę $\mathrm{z}$ epidemią. Zaraził się dżumą w 1815 roku, ale wyzdrowiał dzięki ziołowej terapii własnego pomysłu.

W 1822 Frari pojechał do Werony, a trzy lata później był już w Wenecji, gdzie pracował jako epidemiolog. Pisał też eseje. Został przewodniczącym miejskiej służby zdrowia w Wenecji (1830-1843 oraz 1848-1849). W 1835 roku przebywał w Egipcie jako konsultant w zakresie leczenia dżumy w czasie panującej tam epidemii. W latach 1848-1849 uczestniczył w rewolcie weneckiej przeciw wpływom Cesarstwa Austro-węgierskiego. Cesarz Franciszek Józef uhonorował go złotym medalem za walkę z epidemią dżumy. Frari przyjaźnił się z włoskim pisarzem i patriotą Niccolò Tommaseo, który wspomina go w swoim Diario intimo. Zmarł w Wenecji w 1865 roku.

Frari jest autorem wielu esejów oraz traktatów, między innymi Storia dele febbre epidemica che regnò a Spalato e luoghi vicini nell'anno 1817 czy Cenni storici

\footnotetext{
${ }^{4} \mathrm{Z}$ tych właśnie źródeł wiedzę czerpał Alessandro Manzoni, pisząc najpierw Fermo e Lucia (1823), potem I sposi promessi (1827) i ostatecznie I promessi sposi (1840).

${ }^{5} \mathrm{~W}$ literaturze europejskiej ostatnich wieków o epidemiach pisali: Daniel Defoe (Dziennik roku zarazy), Albert Camus (Dżuma), José Saramago (Miasto ślepców), Herbert George Wells (Kraina ślepców), Samuel Pepys w dziennikach z lat 1660-1669. W literaturze polskiej temat dżumy pojawił się u Adama Mickiewicza w Konradzie Wallenrodzie, a także u Juliusza Słowackiego w Ojcu zadżumionych.
} 
sull'isola di Poveglia e sulla sua importanza sotto l'aspetto samitario. Zapomniane od lat dzieło Della peste e della publica amministrazione samitaria zostało opublikowane w 1840 roku. Autor przedstawia się na wstępie jako lekarz i doradca rządu, przewodniczący magistratu służby zdrowia w Wenecji, członek wielu stowarzyszeń naukowych i akademii włoskich i zagranicznych. Wskazuje też motto, które przyświeca jego działaniom - są to słowa Seneki: Avertere a populo pestem.

Della peste jest zarówno traktatem medycznym o dżumie, jej historii, objawach i sposobie leczenia, jak i relacją o wydarzeniach przeżytych bezpośrednio przez autora. Zawiera opis poprzednich, historycznych fal epidemii dżumy wraz z przeglądem wszystkich dzieł o dżumie $\mathrm{z}$ wcześniejszych epok napisanych w różnych językach ${ }^{6}$. W traktacie nie brakuje też rozważań filozoficzno-etycznych o ludzkiej naturze, moralności, decyzjach, postawach w obliczu katastrofy. Frari opisuje przypadki heroizmu i nikczemności w zajętych zarazą miastach, podając dane, nazwiska, miejsca zdarzeń. Komentuje, ocenia, przestrzega. Przywołuje mity, legendy, opowieści o dżumie krążące w Italii i poza jej granicami. Dzieło dostarcza informacji o funkcjonowaniu ówczesnej służby zdrowia i zawiera wskazówki dla osób pragnących uniknąć zarażenia.

Zwracając się w dedykacji z 4 marca 1840 roku do grafa Franza Antona von Kolowrat-Liebsteinsky, premiera rządu Cesarstwa Austriackiego, Frari wskazuje cel napisania traktatu - pragnie uchronić ludzi przed morową zarazą. Zaznacza, że zamierza skupić się na naturze i tajemnicach dżumy, nie zaniedbując jednak tematów takich, jak higiena publiczna, braki i błędy medycyny, wysiłki służby zdrowia i potrzeba jej reformy. Ma zamiar wskazać rządzącym drogę postępowania, ponieważ „zadaniem uczciwego obywatela” jest ukierunkowanie decydentów „ku prawdzie" i ułatwienie rządowi przyswojenia wiedzy przydatnej w celu zapewnienia dobra wspólnego. Posłuży się zatem swoim „rozumem”, swoją fachową wiedzą, wieloletnim doświadczeniem medycznym (Frari 1840: 25).

Włoski medyk wyznaje, iż Della peste stanowi owoc wytężonej pracy, potu i nieprzespanych nocy poświęconych badaniom. W tym dziele - zachęca do lektury można odnaleźć „odmalowane wielkie nieszczęścia ludzkości”, które obudzą w czytelniku „drżenie współczucia” dla cierpiących i zrozumienie dla potrzeby ochrony i finansowania badań naukowych w zakresie medycyny. Dżuma jest plagą gatunku ludzkiego, która „miasta kwitnące i zaludnione zamienia w bezludną pustynię", „sieje wszędzie zniszczenie”, przygotowując zgubę także dla przyszłych pokoleń (Frari 1840: 10-14). Autor zaznacza, iż ten, kto nie widział „rzezi” spowodowanych

\footnotetext{
${ }^{6}$ Frari utworzył katalog dzieł i traktatów o dżumie, które zostały napisane w różnych krajach i językach, opatrzył owe dzieła komentarzami i wyciągnął z nich wskazówki. Podzielił autorów na tych, którzy przeżyli sami dżumę, którzy wyzdrowieli, którzy sami jej nie doświadczyli, ale ją widzieli, także na tych, którzy tylko o niej słyszeli. Wskazuje ich pochodzenie i zawód - lekarze, historycy, kronikarze, filozofowie, teoretycy, praktycy, urzędnicy i inni. Praca kosztowała go, jak wyznaje, ,niezmierny trud” (Frari 1840: 29).
} 
dżumą, ten nie może sobie wyobrazić bezmiaru tragedii. Nie chodzi już tylko same cierpienia fizyczne ofiar moru, ale i o skrajne emocje towarzyszące ludziom w miejscach ogarniętych epidemią - są to paraliżujący strach, niepokój, samotność, rozpacz. Epidemia zagraża zdrowiu fizycznemu i psychicznemu obywateli, ich szczęściu i pomyślności, tym samym więc „nie może nie budzić zainteresowania różnych rządów". Autor domaga się odpowiedzialnej i mądrej polityce prozdrowotnej, która winna zabezpieczać potrzeby ludzkie, zachowując w społeczeństwie „bezcenny skarb zdrowia”. Od dobrze prowadzonej polityki zależy siła państwa i „wielkość polityczna narodu" (Frari 1840: 15).

Dla tak szlachetnego celu należy zrobić wszystko co tylko możliwe, chroniąc przed zarazą całe społeczeństwa i każdą jednostkę z osobna. Frari zachęca do podejmowania wysiłków w celu finansowania badań i działań lekarzy. Potępia zarazem tych rządzących, którzy z zaniedbania, z „niezdrowej obojętności”, z ociągania się, z powodu „niskich instynktów”, dla prywaty zaniedbują te kwestie. Są ignorantami, którzy nie rozumieją, że szybkość rozprzestrzeniania się zarazy jest piorunująca - gdy trafi ona pod strzechy ubogich to tak, jak gdyby była już za ,progiem pałaców bogaczy”. A wówczas królować zaczyna „generalny bałagan”, chaos, panika. Jeśli zło już się rozsiało, zatrzymać go nie sposób - czas reagowania jest tu zatem najważniejszy. Ostrzega też, że współobywatele - zarówno martwi w zaświatach, jak i pozostali przy życiu, nigdy nie zapomną rządzącym rażących zaniedbań. Dręczyć będą ich pretensjami i nienawiścią, przypominając błędy na każdym kroku. Apeluje zatem o sprawne działania, o niemarnowanie czasu na wdrażanie środków „śmiechu wartych i daremnych”, na konsultowanie osób niekompetentnych i wysłuchiwanie niewłaściwych opinii - to wszystko jest skandaliczne i bezużyteczne w czasach pandemicznych. Potępia szczególnie tych, którzy zabierają głos w sprawach, na których się nie znają. Historia ludzkości, twierdzi autor, obfituje w liczne przykłady epidemii, które zebrały ogromne żniwo z ludzkiej winy, z powodu niewybaczalnych błędów rządzących. Tak wielkiej liczby ofiar można było wielokrotnie uniknąć, gdyby osoby odpowiedzialne za ochronę zdrowia publicznego, nie „zdradziły biednej ludzkości”, którą miały wszak chronić (Frari 1840: 15-16).

Autor traktatu zaznacza wyraźnie, że spośród chorób zakaźnych dżuma jest jedną z najtrudniejszych do rozpoznania. Na początku można ją pomylić z innymi chorobami zakaźnymi. W ciągu wieków ludzkość uczyniła tylko minimalny postęp w jej diagnozowaniu. Frari nie waha się podawać konkretnych przykładów tragicznych pomyłek lekarzy, wskazując winnych z imienia i nazwiska. I tak czytelnik dowiaduje się, że wybitny lekarz Niccolò Massa nie potrafił zdiagnozować pierwszych przypadków dżumy w Wenecji, które zapoczątkowały potężną epidemię w latach 1555-1556 (Frari 1840: 106). Podobna sytuacja miała miejsce w latach 1575-1576, gdzie dwaj wybitni profesorowie z Padwy Mercuriale i Capodivacca wezwani przez Republikę Wenecką na pilne konsultacje nie byli w stanie zdiagnozować poprawnie dżumy. $\mathrm{Z}$ ich winy zaniedbano środki ostrożności i wybuchła zaraza, która pochłonęła nie- 
mal 60.000 ofiar. Tak samo stało się w Palermo, gdzie główny lekarz Sycylii Filippo Ingrassia nie rozpoznał dżumy we wstępnym stadium (1576), jak również na północ od Mediolanu (epidemia w latach 1629-1631), gdzie lekarze i chirurdzy wręcz negowali przypadki dżumy. W Weronie w 1630 roku, pomimo dużej śmiertelności i typowych objawów, nie brakowało medyków, którzy poddawali w wątpliwość występowanie moru. Jeszcze gorzej było w czasie weneckiej epidemii z lat 1630-1631, gdy zwołano konsylium 36 znamienitych medyków, którzy pokłócili się w tej kwestii i odwiedli rządzących od podejmowania niezbędnych działań. Ich karygodne postępowanie spowodowało błyskawiczny postęp pandemii, której nie udało się już pokonać (w ciągu 11 miesięcy pochłonęła aż 94.000 ofiar). Tak samo zdarzyła się we Florencji w 1630 roku, w Neapolu i w Genui w 1656 roku (Frari 1840: 107). Sytuacje owe Frari komentuje, nie szczędząc gorzkich słów krytyki i napomnienia. Wspomina też poruszający przypadek epidemii w Messynie, gdzie z powodu ,ignorancji lekarzy i niedowiarstwa urzędników życie straciło 28.000 mieszkańców na 40.000 (Frari 1840: 110).

Wyjątkowo skandaliczny przypadek dotyczy epidemii maltańskiej z 1813 roku, przywleczonej przez angielski statek przybyły z Aleksandrii, którego załoga była już chora $\mathrm{w}$ trakcie rejsu. Maltańscy lekarze zaprzeczali ewidentnej diagnozie angielskich lekarzy i nawet, gdy pojawiły się pierwsze zachorowania, ludzie dalej gromadzili się na placach, na procesjach, odwiedzali chorych, a nawet ukrywali ich przed policją. W konsekwencji mór spowodował niemalże wyludnienie Malty (Frari 1840: 116).

Frari ocenia surowo stan wiedzy wielu współczesnych mu lekarzy, twierdząc, iż żaden spośród absolwentów włoskich uczelni nie umiałby rozpoznać prawidłowo dżumy. Na przestrzeni wieków myliły się przecież wielkie autorytety, lekceważąc konieczność nieustannego pogłębiania wiedzy na temat „choroby tajemniczej, najtrudniejszej do rozpoznania i najbardziej niebezpiecznej” (Frari 1840: 118-119) ${ }^{7}$. W opinii autora Della peste błędy diagnostyczne nie mogą jednak decydować o życiu obywateli miast. Należy zatem publikować więcej na temat dżumy, uzupełniać wiedzę i solidnie szkolić młodych lekarzy, tak, aby natychmiast umieli rozpoznać pierwsze przypadki choroby na danym terytorium. Szkolenie powinno być nie tylko teoretyczne, ale i praktyczne - najlepiej w krajach Wschodu.

Włoski autor wysuwa podejrzenie, iż zdarzało się niejednokrotnie w ciągu wieków, że medycy, postawiwszy początkowo złą diagnozę, obstawali przy niej, mimo, iż zorientowali się, że chodziło o czarną śmierć. Ze wstydu nie chcieli przyznać się do błędu. Autor grzmi: „Nasza pycha nie pozwala nam pokazać, że daliśmy się oszukać ani też wyznać szczerze, że nie mieliśmy racji, staramy się często ukryć błąd nawet przed nami samymi”. Aby móc „zawrócić” i wyznać prawdę, potrzebna

\footnotetext{
${ }^{7}$ Opinię tę potwierdzają współcześni naukowcy. John Aberth pisze, iż dżuma została uznana za „,najgroźniejszą spośród wszystkich chorób i odpowiada za największą być może śmiertelną pandemię w historii" (Aberth 2012: 31).
} 
jest „siła i wyższość charakteru”, „miłość prawdy i sprawiedliwości”, a to charakteryzuje tylko nielicznych (Frari 1840: 119).

Czytamy w Della peste, iż w historii zmagań ludzkości z dżumą zdarzało się i tak, że medycy powodowani chęcią przypochlebienia się osobie potężnej lub zmuszani groźbą do milczenia, obawiając się też kłopotów i popadnięcia w niełaskę wielmożów, nie oznajmiali nikomu strasznej diagnozy - dla własnej wygody i dla własnego ratunku (Frari 1840: 120). Autor przyznaje, że ludzie wielcy, bogaci i potężni nie lubią złych wieści ani żadnych „spraw ponurych”, źle przyjmują ostrzeżenia i upomnienia, a tym bardziej nie mogą ścierpieć obwieszczania im problemów czy katastrof. Medycy mogli zatem obawiać się ich niezadowolenia czy nawet gniewu. A lud, z kolei, lubi spędzać czas przyjemnie i żyć beztrosko, dlatego odczuwa nienawiść, przeklina, atakuje, a nawet eliminuje tych, którzy wieszczą nieszczęścia, z obawy przed utratą ,swoich małych zysków”. Wpływowa klasa kupców i handlarzy obawia się zmiany, braku stabilizacji, ustania handlu i ma w tym interes, aby dementować „,alarmujące głosy o dżumie” i nie dopuścić do wprowadzenia restrykcyjnych środków sanitarnych. Władze zaś obawiają się zamieszek, dezaprobaty, narażenia siebie i wzięcia na siebie odpowiedzialności za różne działania, które powinno się podjąc bezzwłocznie (Frari 1840: 120-122) ${ }^{8}$.

Pisarz zauważa, że wybuch epidemii oznaczał dla wszystkich duże komplikacje, czasem też brakowało środków i możliwości walki z chorobą; niekiedy możliwości były, ale nikt nie chciał ponosić kosztów. Dlatego niektórzy z rządzących minionych epok popierali opinie zaprzeczające wybuchowi epidemii, chcąc wszystkich zadowolić. Takie sytuacje musiały zdarzać się, w ocenie pisarza, nierzadko. Pociągały za sobą opóźnienia we wprowadzaniu obostrzeń, doprowadzając do lokalnej hekatomby. Był to czas próby człowieczeństwa, gdzie zwykli ludzie byli zmuszeni do wybierania między heroizmem a tchórzostwem, między dobrem a złem.

Dramatyczne informacje zawarte w Della peste potwierdzają inne źródła. Jan Kracik pisze, że „władze miejskie w wielu krajach Europy, nie chcąc wywoływać popłochu, na początku epidemii zwlekały z ogłoszeniem kwarantanny, zakazywały żałoby. Badano pierwsze przypadki, medycy rozpraszali budzące się niepokoje, stawiali kojące diagnozy [...]”. Nie było bowiem łatwo „spojrzeć w twarz nadciągającej grozy. Przestać oszukiwać drugich i siebie, ogłosić alarm. Przerwanie kontaktu ze światem, zamykanie kramów, warsztatów, oznaczało stratę w interesach, brak pracy, trudności zaopatrzenia, uliczne rozruchy [...]" (Kracik 1991: 80-81).

Frari nie oszczędza brutalnych opisów choroby. Wyjaśnia, że jej przebieg różnił się często w zależności od tego, czy była to dżuma dymienicza czy krwotoczna. Lecz jedno było pewne - ludzkość od zawsze zdawała sobie sprawę z wysokiego

\footnotetext{
${ }^{8}$ Sonia Shah pisze: „W XIX w. najczęściej obiektami agresji stawali się lekarze i przywódcy religijni. [...] Ludzie obrzucali kamieniami i atakowali miejscowych lekarzy, oskarżając ich o celowe zabijanie pacjentów [...] (Shah 2020: 179).
} 
stopnia jej zjadliwości. Włoski autor pisze o palących pęcherzach pojawiających się na ciele chorych, o gorączce i dreszczach, wymiotach, nieugaszonym pragnieniu, o obłędzie chorych, płaczu i żałobie zdrowych, o bolesnej agonii, o porzuconych dzieciach, o ciałach leżących na ulicach miast. Ludzie obawiali się siebie nawzajem. W Pokonać czarna śmierć Kracika czytamy: „Dotknięty zarazą stawał się niebezpieczny, swój zmieniał się w obcego, ktoś najbliższy zaczynał zagrażać życiu. [...] Wynaturzały się relacje między ludźmi [...]" (Kracik 1991: 5).

Korzystali na tym monatti, grabarze i karawaniarze, który zajmowali się pochówkiem zwłok. Często wchodzili do domów nie tylko po to, by zabierać zmarłych, ale także aby szantażować jeszcze żywych wrzuceniem ich dołów grzebalnych, domagając się złota, jadła lub świadczeń seksualnych. Zaś ciała niedbale pochowane stawały się posiłkiem dla wałęsających się psów. Na polach leżących odłogiem snuły się zwierzęta gospodarskie bez żadnego nadzoru, które padały łupem wilków.

Angelo Antonio Frari przedstawia w swoim dziele wiele praktycznych informacji dla lekarzy i urzędników dotyczących diagnozowania choroby i postępowania w razie wybuchu epidemii, a dla przeciętnych obywateli ukazuje sposoby ratowania życia swojego i bliskich. Jedną ze wskazówek jest obserwowanie natężenia gorączki $\mathrm{u}$ chorego i czas jej występowania. Istotną rzeczą jest też widok osoby chorej na dżumę - jej twarz przybierała charakterystyczny wyraz groteskowej maski zwany facies pestilentialis. Chory wyglądał, jak gdyby był „pijany i zrozpaczony zarazem”, skóra stawała się nienaturalnie blada, potem zmieniała kolor w kierunku czerwieni lub fioletu. Charakterystyczny dla chorych na dżumę był słodkawy zapach, którzy odczuwali jeszcze przed pojawieniem się ewidentnych symptomów choroby, potem pachnieli nim oni sami i wszystkie ich rzeczy. Ów zapach był trudny do usunięcia, powodował go proces martwiczy zachodzący w organizmie. Charakterystyczny był także wygląd oczu chorych - mętnych, niewrażliwych na światło, zgaszonych, o rozszerzonych źrenicach, często łzawiących lub nabiegłych krwią.

Zaś przy braku symptomów typowych dla dżumy należało, w opinii włoskiego medyka, zwrócić uwagę na dreszcze, ból głowy, gęsią skórkę, zawroty, charakterystyczny chwiejny chód, ból nóg, nudności, wymioty, zmęczenie, apatię lub delirium (Frari 1840: 126-127). Niektórzy chorzy wpadali też w nadmierną wesołość, inni rzucali się w szale z okna lub wskakiwali do rzeki. Dużą pomocą w diagnozowaniu była też autopsja zwłok, która w przypadkach wątpliwych mogła być rozstrzygająca ${ }^{9}$.

Frari przestrzega, że choroba przebiega różnie w różnych miejscach świata. Wspomina o falach pandemicznych, gdy dżumę przeżywały głównie dzieci poniżej 8 lat i kobiety we wczesnej ciąży (Frari 1840: 545) oraz o takich, gdzie właśnie te grupy umierały najszybciej. U jednych osób pojawiały się wykwity skórne i opuchnięcia, u innych była tylko gorączka. Choroba mogła przebiegać powoli, trwać kilka

\footnotetext{
${ }^{9}$ Autor poświęca cały rozdział traktatu autopsji pośmiertnej, wskazując ogromne spustoszenia poczynione w ludzkim organizmie przez dżumę we wszystkich narządach.
} 
dni lub mieć działanie natychmiastowe. Autor opisuje sytuacje, gdy spowiednicy przychodzili do umierającego i umierali razem z nim, niemal natychmiastowo (Frari 1840: 610). Chodziło tu z pewnością o dżumę septyczną.

$\mathrm{Na}$ Bliskim Wschodzie spostrzegano pewne znaki w przyrodzie zapowiadające pojawienie się dżumy: włoski autor pisze o ptakach porzucających w pośpiechu swe gniazda, o wielkiej liczbie owadów, o głośniej rechotających żabach, o dużej częstotliwości śmierci zwierząt (Frari 1840: 586).

Ukazawszy skutki dżumy i grozę jej przebiegu, autor proponuje nowoczesne na owe czasy rozwiązania, które tam, gdzie były właściwie stosowane, pozwalały ograniczać rozprzestrzenianie się chorób zakaźnych. Do takich rozwiązań należały lazarety powstałe dzięki „mądrości Wenetów”, które rozprzestrzeniły się na różne kraje europejskie, a także odpowiednie regulacje w zakresie kontaktów handlowych z Orientem.

Nie do przecenienia była rola współczesnych autorowi lekarzy, nielicznych, którzy bezpośrednio walczyli z „potężnym wrogiem”. Frari sławi „nieustraszonych i umiejętnych Medyków”, którzy z odwagą i z zaparciem siebie samych” pomagali chorym i umierającym. Są godni „największej pochwały” (Frari 1840: 17) i stanowią „ozdobę rodzaju ludzkiego” (Frari 1840: 27) ${ }^{10}$. Wielu z nich wyjeżdżało na Wschód, zbierając przydatne informacje na temat dżumy i konsultując się z tamtejszymi medykami. Jednakże, pomimo tak wielkiego zaangażowania i zapału oraz coraz większego doświadczenia i rozwoju wiedzy medycznej, autor dostrzega w swoich czasach rażące zacofanie w materii medycyny. Zastanawia się zatem, jak może to mieć miejsce „pomimo wpływu wieku oświeconego, tak płodnego w odkrycia”, wieku, w którym toczył się „wyścig na wynalazki” (Frari 1840: 18), w czasach coraz intensywniejszych kontaktów handlowych ze Wschodem, „zbliżenia różnych ludów i dalekich narodów”. W świecie, który „przyspiesza” i ma nowe oczekiwania, nowe zainteresowania i potrzeby, szczególną uwagę należałoby poświęcić właśnie sprawom ochrony zdrowia publicznego (Frari 1840: 18) ${ }^{11}$. Autor Della peste apeluje o zniesienie przestarzałych i uciążliwych praktyk zdrowotnych, o zreformowanie sprawy żeglug i przewozu towarów. Chwali zarazem pożyteczne rozwiązania - wspomina

${ }^{10}$ Pisze o bohaterskim lekarzu Bulard, który powodowany miłosierdziem i miłością do wiedzy, ryzykując życie, wytrwale i odważnie, podjął się badań nad dżumą, narażając się przez wiele lat na niedogodności i na bezpośrednie niebezpieczeństwo utraty życia (Frari 1840: 100).

${ }^{11}$ Opowiadając o walce z dżumą w Egipcie i na Bliskim Wschodzie, w imperium otomańskim, w krajach basenu Morza Śródziemnego, włoski autor wspomina o niezwykle prężnej polityce prozdrowotnej w krajach Wschodu. Sprowadzano europejskich lekarzy, przeznaczano ogromne kwoty na edukację prozdrowotną, stosowano środki karne za nieprzestrzeganie obostrzeń - najczęściej karę śmierci za łamanie obostrzeń. Szczegółowo regulowano kontakty międzyludzkie i handlowe, sprawy związane z podróżą, dezynfekcje domów, budowano lazarety dla zakażonych bądź po kwarantannie i szpitale dla zadżumionych oraz dla rekonwalescentów. Domy dezynfekowane specjalnymi „perfumami”, odmalowywane na nowo lub palono. 62-3 Podając fakty, powołując się na dokumenty, relacje, listy z epoki autor udowadnia skuteczność kwarantanny w przypadku dżumy (Frari 1840: 47, 62-63, 67-68). 
o zwołaniu europejskiego kongresu zdrowia, ogłoszonego w 1832 roku, w którym uczestniczyli lekarze i przedstawiciele władzy, zwłaszcza ,potęg morskich”. Chodziło o podzielenie się doświadczeniem i ujednolicenie praktyk w zakresie zapobiegania i zwalczania dżumy i innych ciężkich chorób zakaźnych. Należało bowiem wyjść ,ze strachu wieków ignorancji, czasów przerażenia i terroru”. Nowa Europa miała być zdrowsza i bliższa sobie, przynajmniej handlowo (Frari 1840: 19) ${ }^{12}$.

Pisarz patrzył z nadzieją na ambitne plany wielu rządów, zarazem jednak zastanawiał się, czy pomysły nie zakończą się jedynie wzniosłymi deklaracjami, nadprodukcją niepotrzebnych dokumentów, zapełnianiem „zakurzonych archiwów”. Obawiał się, iż w ludzkim świecie wielkich planów jak zwykle przeważać będą biurokracja i indywidualne interesy, które mogą wypaczać dobre intencje ,przyjaciół dobra” i „zdradzić interes uniwersalny społeczeństwa” (Frari 1840: 20). Miażdżąca jest bowiem krytyka mentalności ludzi nauki i władzy w traktacie Della peste, porażające są wnioski. Frari pisze: „[...] język prywatnych ambicji, niskiej zazdrości, zawiści, potrafi łatwo się maskować pod kłamliwymi pozorami gorliwości o sprawy publiczne, miłości dobra i sprawiedliwości”. Wspomina o hipokryzji, o aroganckiej, nadętej ignorancji, która narzuca się bezwstydnie, a którą należy obnażyć, ośmieszyć i odrzucić. Spotkania uczonych, lekarzy, państwowców, „mądrych i oświeconych", ludzi dobrej woli, którzy pragną współdziałać dla dobra ludzkości powinny być pozbawione prywaty, fałszu i zazdrości (Frari 1840: 21). Nic nie może zakłócić pracy nad przygotowaniem terenu do walki z epidemiami.

Włoski pisarz przypomina, iż historia ,nie zamyka się przed mędrcem” i pozwala mu czerpać ze swojej skarbnicy, ucząc go tego, co nastąpi. Apeluje zatem o przypomnienie sobie błędów wcześniejszych pokoleń, o odróżnianie prawdy od fałszu „W ciemności niepewności przeciwstawnych sobie doktryn”. Jedynie historia i doświadczenie pozwalają omijać „rafy” wzniesione przez ludzką ignorancję, bezczelną dumę oraz konflikt interesów, tak typowy dla świata ludzi (Frari 1840: 30).

Autor Della peste podkreśla i docenia dużą rolę Wenecjan w walce $\mathrm{z}$ chorobą. W średniowieczu weneckie statki przewoziły krzyżowców na Bliski Wschód i utrzymywały kontakty handlowe z Azją, szczególnie z Egiptem i Syrią. Owe okręty, powracając $z$ bogactwami, towarami i niewolnikami, przywoziły niejednokrotnie choroby. Powołując się na źródła z epoki pisarz informuje, że między rokiem 1000 a 1400 Wenecja czterdzieści razy przeżyła epidemię dżumy, a 16 razy w samym XIII wieku (Frari 1840: 34). Wenecjanie, nie chcąc tracić cennych kontaktów i ogromnych zysków z handlu, zmobilizowali zatem wszystkie siły do walki z niewidzialnym wrogiem. Oni to wpadli na pomysł izolowania chorych i zarażonych towarów, które przywozili z dalekich krajów. Wenecja otoczona przez małe wysepki

\footnotetext{
${ }^{12}$ Frari propagował pomysł ustanowienia systemu służby zdrowia jednolitego we wszystkich krajach, aby zagwarantować bezpieczeństwo publiczne, interesy żeglugi i handlu, ustalić sposoby dezynfekcji towarów i osób. Potrzebna była „radykalna reforma sanitarna”. Podkreślał korzyści płynące z obostrzeń związanych z ,rygorystyczną kwarantanną" (Frari 1840: 86).
} 
zdecydowała się przeznaczyć w 1403 roku jedną z nich (Santa Maria di Nazareth) na miejsce kwarantanny dla chorych i podejrzanych o zachorowanie oraz do przechowywania towarów. To Wenecja, podkreśla autor, jako pierwsza ustanowiła we Włoszech kwarantannę i zapoczątkowała budowę lazaretów, stanowiąc wzór dla całej Europy ${ }^{13}$.

Badając naturę dżumy i sposoby zapobiegania wybuchowi epidemii, Frari przestrzega, iż jest to choroba zdradliwa - zdarzają się przypadki zarażenia dżumą w sposób bezobjawowy. Ponadto, dżuma ma niekiedy dłuższy okres inkubacji (nawet 15-20 dni w porównaniu do normalnego czasu inkubacji od 1 do 12 dni) (Frari 1840: 71-74). Stąd tak wielka rola kwarantanny. Zapobiegając rozsiewaniu zarazy, nie można zapominać o tym, że rzeczy, zwłaszcza ubrania czy futra, zamknięte w kufrach i szafach, gdzie brakuje „tlenu atmosferycznego”, mogą „przetrzymywać chorobę" bardzo długo i „zarażać po otwarciu, w sprzyjających okolicznościach”, roznosząc chorobę na duże odległości, nawet po latach (Frari 1840: 78) ${ }^{14}$. Dlatego za radą autora należało uznać wszystkie towary pochodzące ze Wschodu lub $\mathrm{z}$ miejsc podejrzanych za potencjalnie zarażone. W opinii włoskiego medyka kwestia dezynfekcji była rażąco zaniedbywana w Europie, w niektórych lazaretach przeprowadzano ją w sposób niewłaściwy, daremny i wręcz ,śmieszny”. Apeluje do rządów Europy o zrewolucjonizowanie lazaretów, o ustalenie prostych i klarownych sposobów dezynfekcji, bez „nieracjonalnego i przesadnego rygoru”, który bezzasadnie „paraliżował” handel i zagrażał „,dobrobytowi narodowemu” (Frari 1840: 82) ${ }^{15}$.

W lazaretach Europy panował bowiem chaos, każdy ustalał swój okres kwarantanny (od 10 do 40 dni) i swój własny sposób dezynfekcji (chlorem, powietrzem, gorącem, ziołami, eksperymentalnymi miksturami itp.). Były lazarety, w których jedynie odkładało się rzeczy na bok na dwa tygodnie i takie, gdzie stosowało się wszystkie środki naraz, dodając do tego jeszcze dezynfekcję dymem lub siarką. Bywało i tak, że towar przybywający „ze zdrowego kraju do zdrowego kraju”, ale

${ }^{13}$ Frari wyjaśnia etymologię słowa lazaret - na wyspie mieścił się wcześniej klasztor i kościół Matki Bożej z Nazaretu. Początkowo owe miejsca odosobnienia nazywano Nazaretem, ale łatwiej wymawiało się lazaret i z czasem n zastępowano 1 - dla łatwości wymowy. A ów wenecki lazaret, pierwszy w Europie, za czasów autora upiększony i powiększony, wspaniale umeblowany, autor zalicza do najpiękniejszych i najwygodniejszych lazaretów Europy (Frari 1840: 36-37).

${ }^{14}$ Autor przywołuje przypadek otwarcia klasztornego archiwum we Włoszech z czasów zarazy 4 lata po epidemii - dżuma zaatakowała ponownie i zabiła wszystkich mnichów. Pisze też o słynnym przypadku z Wrocławia - prześcieradło wyjęte z kufra po 14 latach spowodowało nawrót dżumy w 1542 roku. W ciągu 22 tygodni zmarło 4900 osób i epidemia rozniosła się na cały Śląsk (Frari 1840: 78-80).

${ }^{15}$ Krytykuje stosowaną praktykę czterdziestodniowej kwarantanny odzieży osób zadżumionych i przedmiotów handlu zamykanych w lazaretach i sprawdzanych bezsensownie dwa razy dziennie, podczas gdy zdaniem autora, w celu usunięcia źródła zakażenia, wystarczy wystawić owe rzeczy na działanie powietrza i gorącej temperatury, bądź solidnie wyprać. W ten sposób można zdezynfekować także odzież zabrudzoną krwią czy innymi wydzielinami chorych. Opisuje ową praktykę zastosowaną przez niego w lazarecie w Splicie w 1817 roku. W ciągu kilku dni zdezynfekował skutecznie w ten sposób przedmioty i odzież należące do 46 rodzin zmarłych na dżumę. Owe przedmioty zostały przekazane następnie innym osobom, z których żadna nie zaraziła się dżumą. 
poprzez „kraj zarażony”, puszczano w obrót od razu, bez dezynfekcji. Autor traktatu głosi potrzebę „mądrej legislacji europejskiej” i pilnego ujednolicenia praktyk we wszystkich krajach, które ze sobą handlują (Frari 1840: 84). Przeciwny jest zarazem pomysłowi kilku autorytetów medycznych swoich czasów, które proponowały badać stopień zaraźliwości dżumy na więźniach skazanych na karę śmierci, którzy w ten sposób mieliby szansę zginąć ,śmiercią chwalebną". Włoski autor potępia moralnie pomysł owych straszliwych eksperymentów”. Pyta: „jak można mieć nadzieję, że taki pomysł zostanie dobrze przyjęty w Europie"? (Frari 1840: 85). Nie zamierza skazywać na cierpienie „nieszczęśliwych ofiar”, lecz ośmiela się wzywać „panów sędziów" do poświecenia się nauce i dobru ludzkości, pozwalając na przeprowadzenie eksperymentów na ich własnej skórze (Frari 1840: 87).

Świat nauki powinien połączyć wspólne wysiłki na „drodze postępu”, po to, aby mogły skorzystać z tego przyszłe pokolenia. Za szczególnie pilną sprawą uważał Frari zbadanie czynnika odporności na dżumę, zauważył bowiem, iż niektórzy pacjenci nie zarażali się, pomimo przebywania pod jednym dachem $\mathrm{z}$ chorymi. Zastanawia się, co miało na wpływ na rozprzestrzenianie się choroby - klimat, pogoda, gorąco, światło czy może powietrze (Frari 1840: 89) ${ }^{16}$.

$\mathrm{Na}$ koniec autor traktatu proponuje ludzkości skuteczne rozwiązania problemu. Pierwszym krokiem powinno być natychmiastowe rozpoznanie choroby, izolacja podejrzanych i dezynfekcja (Frari 1840: 605). Istotne było wietrzenie i okadzanie pomieszczeń. Jeśli w tym samym domu zachorowało lub zmarło kilka osób, należało bez wahania obarczać winą dżumę. Także odzież i towary z zagranicy należało zawsze traktować jako podejrzane i poddawać kwarantannie. Marynarze powinni przybijać do portów ze pozytywnymi świadectwami sanitarnymi, a miasta stanowiące ogniska epidemii należało objąć kordonami sanitarnymi (Frari 1840: 610).

W przebiegu choroby włoski medyk polecał żywienie chorych rosołami na mięsie ze szczawiem lub z innymi kwaskowatymi ziołami lub warzywami. Podaje też skład sporządzanych przez siebie mikstur, za pomocą których należało dezynfekować pomieszczenia i rzeczy.

Rozterki, obawy i rady Włocha żyjącego dwieście lat temu nie straciły na aktualności. Współcześni badacze piszą: „Skoro nie dajemy rady całkowicie zapobiec epidemiom, najlepsze, co możemy zrobić, to wykrywać je jak najszybciej" (Shah 2020: 295). System jest jednak zbyt powolny, pacjenci zero nie zawsze zgłaszają się do lekarza, a medycy nie od razu dostrzegają i zgłaszają dziwne przypadki chorobowe. Są też „luki w systemie tam, gdzie nikt nie patrzy. [...] Całe ciężarówki jedzenia i armie owadów przenoszą choroby przez granice państwowe bez żadnej kontroli $[\ldots]$. A odporne na działanie antybiotyków patogeny [...] wykrywane są wyłącznie przez przypadek”. W ostateczności niszczycielska siła patogenów „krąży

${ }^{16}$ Dzisiejsi biolodzy molekularni twierdzą, że osoby, które przeżyły dżumę miały genetyczną mutację w receptorze CCR5- $\Delta 32$ w białych krwinkach (Duncan, Scott 2008: 182). 
nad nami wszystkimi” (Shah 2020: 298). Jednym z rozwiązań byłby przejrzysty, globalny system reagowania i wczesnego alarmowania o pandemii (Shah 2020: 306).

Czarna śmierć była z pewnością jedną z najgroźniejszych chorób, które dotknęły ludzkość. Jednakże nie ostatnią, bowiem „te śmiertelne zakażenia pojawiają się tajemniczo znikąd, mają swój ustalony przebieg, a następnie znikają. Lecz czasami mogą powrócić. Musimy przyjąć do wiadomości niebezpieczeństwo powtórnego pojawienia się czarnej śmierci; takie zdarzenie mogłoby zniszczyć całą naszą cywilizację" (Duncan, Scott 2008: 217).

Angelo Antonio Frari miał nadzieję na znalezienie w krótkim czasie (50-60 lat) skutecznego leku na dżumę i na całkowite wyeliminowanie zarazy ze społeczeństwa. Nie wiedział nic o patogenach, o mutacjach wirusowych i bakteryjnych, o zawiłościach systemu immunologicznego człowieka, o szczepieniach. Zadziwiłaby go wiedza i oszołomiłyby cuda współczesnej medycyny. Najbardziej jednak zdumiałby się, uświadamiając sobie, że człowiek XXI wieku nadal nie pokonał dżumy, a do tej strasznej choroby dołączyły kolejne plagi. Bez wątpienia rozgniewałaby go beztroska, powolność działań i brak dyscypliny. Uznałby, że ludzkość wcale się nie zmieniła i że nadal jest bezbronna w obliczu epidemii.

\section{Bibliografia}

Aberth, J. 2012. Spektakle masowej śmierci. Plagi, zarazy, epidemie. przeł. L. Karnas. Warszawa: Świat Książki.

Alchon, S.A. 2003. A pest in the land: new world epidemic in a global perspective. New Mexico: University of New Mexico Press.

Boccaccio, G. 1999. Decameron. Torino: UTET.

Bordone, R. i G. Sergi. 2013. Dieci secoli di Medioevo. Torino: Einaudi.

Cosmacini, G. 2005. Storia della medicina e dalla sanità in Italia: dalla peste nera ai giorni nostri. Bari: Laterza.

Delumeau, J. 1986. Strach w kulturze Zachodu XIV-XVIII w., przeł. A. Szymanowski. Warszawa: Pax.

Duncan, C. i S. Scott. 2008. Czarna śmierć. Epidemie w Europie od starożytności do czasów współczesnych. przeł. A. Siennicka. Warszawa: Bellona.

Dziubek, Z. (red.). 2012. Choroby zakaźne i pasożytnicze. Warszawa: PZWL Wydawnictwo Lekarskie.

Frari, A.A. 1840. Della peste e della publica amministrazione samitaria. Venezia: Tipografia Francesco Andreola.

Głowiński, T. i E. Kościk. (red.). 2013. Od powietrza, głodu, ognia i wojny... Klęski elementarne na przestrzeni wieków. Wrocław: GAJT.

Kracik, J. 1991. Pokonać czarna śmierć. Staropolskie postawy wobec zarazy. Kraków: Wydawnictwo M.

Montanari, M. 2006. Storia medievale, Roma-Bari: Laterza.

Shah, S. 2020. Epidemia. Od dżumy przez AIDS i ebole po COVID-19, przeł. M. Rost. Kraków: Znak Horyzont.

Sznajderman, M. 1994. Zaraza. Mitologia dżumy, cholery i AIDS. Warszawa: Semper.

Ujvari, S.C. 2002. Storia delle epidemie. Bologna: Odoya.

Vovelle, M. 1984. La morte e l'occidente. Dal 1300 ai nostri giorni. Roma: Editori Laterza. 